\title{
Metastatic Extracranial Malignant Solid Neoplasm
}

National Cancer Institute

\section{Source}

National Cancer Institute. Metastatic Extracranial Malignant Solid Neoplasm. NCI

Thesaurus. Code C157334.

A malignant solid neoplasm that arises from any anatomic site other than the brain and has spread from its original site of growth to another anatomic site. 